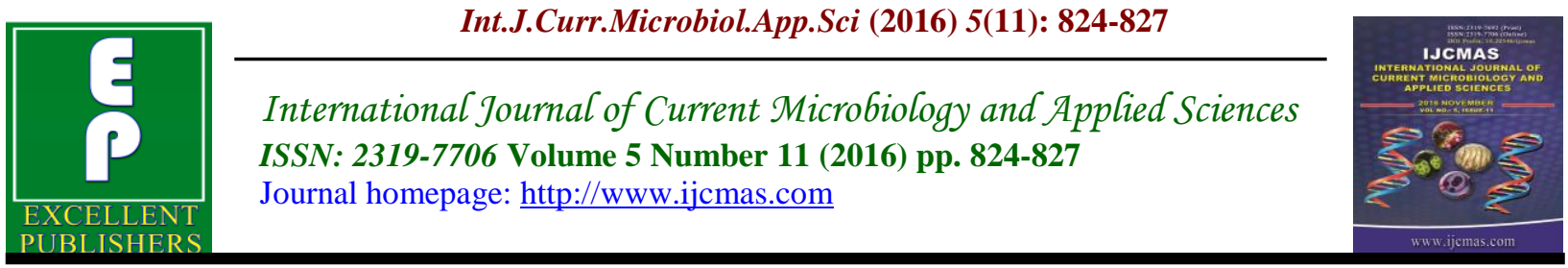

Original Research Article

http://dx.doi.org/10.20546/ijcmas.2016.511.093

\title{
Evaluation Antibacterial Activity of three Most Consumed Tea Extracts against Pathogenic Bacteria
}

\author{
Aziz Fatima $^{1}$, Farah Malik ${ }^{1}$, Amna Shafiq ${ }^{1}$, Sumara Jawaid, ${ }^{1}$, \\ Shazia Tabassum Hakim ${ }^{1}$ and Sayyada Ghufrana Nadeem ${ }^{2}$ \\ ${ }^{1}$ Department of Microbiology, Jinnah University for Women, Karachi - 74600 \\ ${ }^{2}$ Medical Mycology Research and Reference Laboratory, Department of Microbiology, Jinnah \\ University for Women, Karachi - 74600 \\ *Corresponding author email id:
}

\section{A B S T R A C T}

Keywords

Camellia sinensis, Andropogonschoena ntus, Antimicrobial activity, Tea extract, Human pathogens.

\begin{tabular}{l}
\hline Article Info \\
\hline Accepted: \\
26 October 2016 \\
Available Online: \\
10 November 2016
\end{tabular}

Green tea and black tea are derived from the plant Camellia sinensis, while lemon grass belong to Andropogonschoenantusand herbal tea belong to different natural herbs plant. The present study was designed to evaluate the antimicrobial activity of different tea extract against most disease causing human pathogens which include Escherichia.coli, Staphylococcus aureus, Salmonella typhi, Bacillus subtilus, Micrococcus luteus, Proteus vulgaris, Pseudomonas aeruginosa, Klebseila pneumonia, andCitrobacterspps. Antimicrobial components present in these tea extracts have high rate of antimicrobial properties. The antimicrobial activity of these extracts were determined by agar well diffusion technique. In this study black tea and green tea give maximum zone of inhibition against majority of pathogens as compare to lemon grass while on other hand herbal tea give no zone of inhibition.

\section{Introduction}

Tea is the type of beverage which belongs to Camellia sinensisplant (Fuller and Thomas, 2008). Tea is an infusion of leaves that has been consumed for centuries as a beverage and is valued for its medicinal properties. Green tea is non fermented tea originated in China whereas black tea has been the traditionally consumed tea (Graham, 1999). The fermentation process is the key between green tea and black tea. In case of black tea, the leaves and buds are dried before fermentation. While in green tea the leaves are first steamed and then dried. The phytochemicals present in tea leaves are highly sensitive to oxidation process. Green tea contains 30 and 40 percent of water extractable polyphenols, while black tea contains between 3 to 10 percent. Black tea is also known to have potent antioxidant properties which are manifested by its ability to scavenge free radicals, that inhibit lipid, Epicperoxidation, and chelate metal ions. According to the previous studies, four polyphenolic compounds, Epigallocatechigallat

(EGCG) natechingallate $(\mathrm{ECG}), \quad$ Epigallocatechin 
(EGC) and Epicatechin (EC) are significant antioxidants constituents present in tea. Among these EGCG is the most luxuriant component in tea extract and the most potent chemical tested for biological activity (EC). Black tea which is a major source of the aflavins and the arubigins has also been shown to have antibacterial properties both in vivo and in vitro. Lemon grass(CymbopogonCitratus) belongs to the family Germineace. Lemon grass plant due to having alkaloids and phenolic components have also shown antibacterial properties (Stadtman, 1996).

The aim of this research was to evaluate the antimicrobial activity of most consumed tea extracts against pathogenic bacteria.

\section{Materials and Methods}

\section{Collection of samples}

Different tea leaves samples were purchased from the local markets of Karachi for screening the antibacterial activity against some selected gram negative and gram positive isolates.

\section{Preparation of Hot Water Extracts}

Green \& Black Tea Extracts: 25 grams of tea sample were added in $250 \mathrm{ml}$ of hot water. Stirred continuously for 3 times at $120 \mathrm{rpm}$ for $1 \mathrm{hr}$. Filtrate the mixture for extract collection.

Lemon Grass Tea Extract: 25 grams of lemon grass and make fine powder. $500 \mathrm{ml}$ of distilled water were added. Stirred continuously at 120rpm for 8 hours. Filter the extract.

\section{Agar well Diffusion Technique}

Lawn was prepared on MHA plates. Make four wells with a help of borer on each plate for each extract. Pour $100 \mu \mathrm{l}$ of black tea, green tea, lemon grass and herbal tea extract in each well. Use Streptomycin as positive control. Incubate all plates at $37{ }^{\circ} \mathrm{C}$ for 24 hours. Observe the plates and measure zone of inhibition.

\section{Results and Discussion}

The results of the study showed that the leaves extract of Camellia sinensis indicates the presence of potent antibacterial activity, which confirms its use against microbial pathogens including antibiotic resistance bacteria.

Table.1 Antibacterial pattern of black tea

\begin{tabular}{|l|l|l|l|}
\hline Organism & Black tea & Result & Positive control \\
\hline Escherichia coli & $25 \mathrm{~mm}$ & sensitive & $20 \mathrm{~mm}$ \\
\hline K.pneumonia & $23 \mathrm{~mm}$ & sensitive & $25 \mathrm{~mm}$ \\
\hline Bacillus subtilis & $22 \mathrm{~mm}$ & sensitive & $20 \mathrm{~mm}$ \\
\hline M.lutes & $23 \mathrm{~mm}$ & sensitive & $30 \mathrm{~mm}$ \\
\hline S.aureus & $9 \mathrm{~mm}$ & sensitive & $30 \mathrm{~mm}$ \\
\hline S.typhi & $20 \mathrm{~mm}$ & sensitive & $20 \mathrm{~mm}$ \\
\hline Ps.aeroginosa & $21 \mathrm{~mm}$ & sensitive & $23 \mathrm{~mm}$ \\
\hline
\end{tabular}


Table.2 Antibacterial pattern of lemon grass

\begin{tabular}{|c|c|c|c|}
\hline Organisms & Lemon Grass & Result & $\begin{array}{c}\text { Positive } \\
\text { Control }\end{array}$ \\
\hline Bacillus subtilis & $6 \mathrm{~mm}$ & sensitive & $10 \mathrm{~mm}$ \\
\hline Proteus vulgaris & No zone & resistant & $10 \mathrm{~mm}$ \\
\hline Klebsiella pneumonia & $6 \mathrm{~mm}$ & sensitive & $10 \mathrm{~mm}$ \\
\hline Staphylococcus aureus & $6 \mathrm{~mm}$ & sensitive & $12 \mathrm{~mm}$ \\
\hline Escherichia coli & $4 \mathrm{~mm}$ & sensitive & $5 \mathrm{~mm}$ \\
\hline Pseudomonas aeruginosa & $8 \mathrm{~mm}$ & sensitive & $15 \mathrm{~mm}$ \\
\hline
\end{tabular}

Table.3 Antibacterial pattern of green tea

\begin{tabular}{|l|l|l|l|}
\hline ORGANISMS & GREEN TEA & RESULT & $\begin{array}{l}\text { POSITIVE } \\
\text { CONTROL }\end{array}$ \\
\hline Escherichia coli & $23 \mathrm{~mm}$ & sensitive & $20 \mathrm{~mm}$ \\
\hline Klebsiella pneumonia & $4 \mathrm{~mm}$ & sensitive & $25 \mathrm{~mm}$ \\
\hline Bacillus subtilis & $22 \mathrm{~mm}$ & sensitive & $20 \mathrm{~mm}$ \\
\hline Micrococcus luteus & $25 \mathrm{~mm}$ & sensitive & $30 \mathrm{~mm}$ \\
\hline $\begin{array}{l}\text { Staphylococcus } \\
\text { aureus }\end{array}$ & $20 \mathrm{~mm}$ & sensitive & $30 \mathrm{~mm}$ \\
\hline $\begin{array}{l}\text { Salmonellatyphi } \\
\text { Pseudomonas } \\
\text { aeruginosa }\end{array}$ & $20 \mathrm{~mm}$ & sensitive & $20 \mathrm{~mm}$ \\
\hline
\end{tabular}

The assessment of antimicrobial activity was evaluated by agar well diffusion technique in which Green tea gives high and effective zones of inhibition than black tea and herbal tea, Green tea>black tea >lemon grass $>$ herbal tea. These observations may be attributed to green tea catechin compounds and polyphenols. Polyphenols act directly against microorganisms by inhibiting virulence factors. These compounds have been found to possess antibacterial action which protect the body from damage caused by free radical-induced oxidative reactions. There are many health benefits that have 
been reported to consumption of the tea beverage, including, reduction of cholesterol, antibacterial, anti-diabetic, antiinflammatory and antiviral. It is hoped that by use of herbal tea it may help to avoid the side effects of antibiotics. In future, the combined use of tea and antibiotics could be also useful in fighting emerging drugresistant problem especially among enteropathogens.

\section{References}

Almajano, M.P., Rosa, C., and Angel, L.J. 2008. Antioxidant and antimicrobial activities of tea infusions. Food
Chem., 108: 55-63.

Fuller, Thomas. 2008. A Tea from the Jungle Enriches a Placid Village. The New York Times (New York), p. A8.

Graham, H.N. 1999. Tea. In: Frederick JF, editor, Wiley Encyclopedia of Food Science and Technology. 2nd ed. New Jersey: John Wiley and Sons; pp. 1-4.

Stadtman, E.R., 1996. Protein oxidation and aging. Sci., 257: 1220-1224.

Sumpio, B.E., Cordova, A.C., BerkeSchlessel, D.W., Qin, F., and Chen, Q.H. 2006. Green tea the "Asian Paradox and cardiovascular disease. $J$. American College of Surgeons, 202: 813-820.

\section{How to cite this article:}

Aziz Fatima, Farah Malik, Amna Shafiq, Sumara Jawaid, Shazia Tabassum Hakim and Sayyada Ghufrana Nadeem. 2016. Evaluation Antibacterial Activity of three Most Consumed Tea Extracts against Pathogenic Bacteria. Int.J.Curr.Microbiol.App.Sci. 5(11): 824-827. doi: http://dx.doi.org/10.20546/ijcmas.2016.511.093 